\title{
TASAWUF DAN MODERNITAS \\ (Mengikis Kesalahpahaman Masyarakat Awam Terhadap Tasawuf)
}

\author{
Muh. Gitosaroso
}

\begin{abstract}
ABSTRAK
Sampai sejauh ini, masih banyak orang yang salah dalam memahami tasawuf. Kesalahpahaman itu berakibat buruk bagi citra tasawuf di masyarakat. Artikel ini mencoba mengetengahkan tentang fakta bahwa tasawuf tidak seperti yang dipikirkan oleh sementara orang secara negatif. Tasawuf adalah dimensi esoterik dalam Islam. la lahir dari tiga pilar ke-Islam-an melalui sisi Ihsan. Bertasawuf, berarti berupaya mewujudkan al-Ihsan, "Beribadah kepada Allah seolah-olah melihat-Nya; ketika tidak bisa, maka yakin bahwa Allah melihat kita". Sementara itu modernitas bukan hanya menunjuk pada suatu periode, melainkan juga suatu bentuk kesadaran yang terkait dengan kebaruan (Inggris: Newness), karena itu istilah perubahan, kemajuan, revolusi, pertumbuhan dan lain-lain adalah istilah-istilah kunci kesadaran modern. Melalui kesadaran spiritual, tasawuf berhasil menyelesaikan berbagai persoalan spiritual masyarakat, sedangkan modernitas mampu menyelesaikan persoalan materialnya.

Kedua istilah ini (tasawuf dan modernitas), merupakan dua hal yang tidak dapat dipisahkan, saling membutuhkan dan saling melengkapi, bukannya saling bertentangan.

Oleh karena itu, kesalah-pahaman itu harus segera dikikis habis di era yang terus berubah ini.
\end{abstract}

Kata Kunci: Tasawuf, Modernitas dan Salah-Paham

\section{A. Pendahuluan}

Tidak sedikit orang yang salah faham terhadap tasawuf. Sebagian orang mengindentikkan tasawuf dengan orang-orang yang hidupnya anti dunia, anti kekayaan bendawi, anti komunitas sosial, dan lain sebagainya. Sementara lainnya, bahkan ada pula yang lebih ekstrim, yaitu ketika tasawuf didekatkan dengan kehidupan yang penuh dengan kemiskinan, kumuh dan jauh dari kemapanan finansial ${ }^{1}$. Ringkasnya,

\footnotetext{
${ }^{1} \mathrm{Hal}$ ini terjadi ketika orang awam melihat bahwa para Sufi (baca: Penganut Tarekat), banyak menghabiskan waktunya untuk berdzikir dan berdiam diri di padepokan atau di rumah, seolah hanya dengan berdzikir rezeki akan datang dengan sendirinya meski tanpa harus bekerja keras. Atau ketika melihat para pencari ketenangan jiwa yang berbondong-bondong pergi ke sebuah masjid untuk tinggal dan
} 
tasawuf dipandang sebagai "ancaman" bagi gaya hidup (life style) modern yang saat ini digandrungi mayoritas masyarakat. Tasawuf dikira sebagai suatu kehidupan yang tidak boleh mengikuti perkembangan zaman, miskin, terasing, dan beribadah tanpa henti (seperti Puasa, Shalat, Dzikir dan sebagainya dalam waktu dan porsi yang tidak terbatas). Sehubungan dengan salah pemahaman seperti di atas, maka banyak orang awam yang anti terhadap tasawuf ${ }^{2}$.

Pemahaman tersebut tentu saja pemahaman yang keliru. Tasawuf memang tidak ada sejak awal Islam di masa Rasulullah SAW dan para Sahabat, akan tetapi praktik sufistik telah

berdiam diri beberapa hari di sana. Mereka menganggap seperti itulah ajaran tasawuf. Atau mereka membaca sejarah, bahwa sebagian besar para sufi terkemuka harus meregang nyawa di tiang gantungan, bahkan dibakar hidup-hidup (seperti kisah Suhrawardi dan Hamzah Fansuri). Suhrawardi meninggal atas kekejaman fitnah para Fuqaha dalam rezim Salahuddin al-Ayubi (1191 M). Lihat: Henry Corbin, Imajinasi Kreatif Sufisme Ibn Arabi (Yogyakarta: LKiS, 2002), hlm. 19.

2 Terutama di era modern seperti sekarang ini, semakin banyak orang yang salah dalam memahami tasawuf. Banyak yang berpendapat bahwa tasawuf bertentangan dengan ajaran Islam dan tidak ada dasarnya dalam syari'at, baik al-Qur'an maupun Sunnah. Sebab lain adalah munculnya sufi gadungan (pseudo-sufi), yang mengingkari keberadaan syari'at dan membuat aturan-aturan sendiri serta mengklaim memiliki otoritas agung yang ahistoris dan tak berakar pada pendahulu manapun. Syeikh Muhammad Hisyam Kabbani, Ensiklopedia Akidah Ahlusunah: Tasawuf dan Ihsan, Antivirus Kebatilan dan Kezaliman (Jakarta: PT Serambi Semesta, 2007), hlm. 21. kental dalam kehidupan mereka. Pada zaman Rasulullah SAW hidup, semua orang menjadi shufi, yaitu keluar dari budi perangai yang tercela dan masuk ke dalam budi perangai yang terpuji. Baik Nabi dan sahabatnya yang berempat atau yang beribu-ribu itu semuanya berakhlak tinggi, berbudi mulia, sanggup menderita lapar dan haus, dan jika mereka beroleh kekayaan, tidaklah kekayaan itu lekat ke dalam hatinya sehingga melukakan hati itu jika terpisah $^{3}$. Selanjutnya istilah sufi dikenal luas setelah abad ke-3 Hijriyah. Istilah ini dikenal sejak Abu Hasyim al-Kufi al-Sufi (w. $250 \mathrm{H}$ ), dengan meletakkan nama 'Al-Sufi' di belakang namanya. Meskipun sudah banyak orang yang ahli di bidangnya, seperti pemikiran Zuhud, Khauf, Raja', Mahabbah dan Wara' dan Tawakkal, namun dialah yang digelari alSufi ${ }^{4}$.

Jika dilihat dalam lembaran sejarah, ada banyak sufi yang bergerak membela Islam dengan Pedang dan Pena, seperti pengikut Tarekat Naqsyabandiyah, Syamil Daghestani, yang berjuang melawan pasukan Rusia di Kaukasia pada abad kesembilan belas; Sayyid Abdullah al-Somali

\footnotetext{
${ }^{3}$ Hamka, Tasauf Modern (Jakarta:Pustaka Panjimas, 1990), hlm. 15.

${ }^{4}$ M. Amin Syukur, Menggugat Tasawuf: Sufisme dan Tanggung Jawab Sosial Abad 21 (Yogyakarta: Pustaka Pelajar, 2007), hlm. 7.
} 
(Shahiliyah) yang memimpin umat Islam melawan pasukan Inggris dan Italia di Somalia (1899-1920); Usman ibn Fodi (Qadiriyah) yang memimpin jihad di Nigeria Utara (1804-1808); Abdul Qadir al-Jazairi (Qadiriyah) melawan Prancis (1832-1847); Haji Muhammad al-Ahrasy (Darqawiyah) berperang melawan pasukan Prancis di Mesir; Haji Umar Tall (Tijaniyah) di Senegal, dan lain sebagainya hingga revolusi kebudayaan di Cina. Ini menunjukkan bahwa tasawuf sama sekali tidak mendorong manusia untuk berdiam diri, melarikan diri dari dunia, dan merintangi kemajuan masyarakat, tetapi jusru mendorong nilai-nilai sosial serta pengkajian agama dan ilmu serta tak kenal lelah melawan ketidak adilan sosial ${ }^{5}$.

Persoalannya kemudian adalah bagaimana memahamkan dan mengamalkan tasawuf, terutama pada zaman modern yang banyak tantangan dan tuntutan? Oleh karena itu pembahasan tentang tasawuf dan modernitas sangat perlu dan menarik untuk dibahas, agar pembaca tidak salah faham lagi dan alergi dengan tasawuf. Selain itu, pembahasan ini dapat dijadikan solusi dalam menghadapi problematika hidup di abad ini.

\footnotetext{
5 Syeikh Muhammad Hisyam Kabbani, Ensiklopedia Akidah..., hlm. 20.
}

\section{B. Memahami Ajaran Tasawuf}

Tasawuf atau Sufisme adalah salah satu cabang keilmuan dalam Islam, yang secara keilmuan merupakan hasil kebudayaan Islam yang lahir kemudian sepeninggal Rasulullah SAW. Jika dilihat dari akar pemikirannya, maka tasawuf berasal dari konsep Ihsan. Ihsan sendiri merupakan semua tingkah laku Muslim, baik tindakan lahir maupun batin, dalam ibadah maupun muamalah. Ihsan adalah jiwa atau roh dari Iman dan Islam ${ }^{6}$.

Secara ringkas tasawuf adalah suatu norma, aturan, dan ilmu bagaimana orang bisa mendidik jiwa dan hatinya untuk bisa berakhlakul karimah, beribadah, dan selalu mendekatkan diri kepada Allah serta selalu mencari ridhaNya. Oleh karena itu tasawuf adalah jalan yang harus ditempuh oleh setiap individu yang ingin mencari keselamatan hidup di dunia dan akhirat, baik oleh orang-orang yang hidup di masa lalu, masa kini maupun yang akan datang.

\section{Pengertian Tasawuf}

Secara etimologi, terdapat sejumlah kata atau istilah yang berkenaan dengan tasawuf yaitu ahlu suffah (sekelompok orang di masa Rasulullah SAW yang hidupnya banyak

\footnotetext{
${ }^{6}$ M. Amin Syukur, Tasawuf Sosial (Yogyakarta: Pustaka Pelajar, 2004), hlm. 3-5.
} 
berdiam di serambi-serambi masjid), shafa (bersih atau suci), shaf (barisan shalat) dan shuf (bulu domba atau wool). Kata-kata tersebut bisa-bisa saja dihubungkan dengan tasawuf ${ }^{7}$. Ada juga yang mengatakan bahwa kata tasawuf berasal dari kata Sovia yang artinya kebijaksanaan, Sufanah yaitu sejenis buah-buahan kecil dan berbulu yang banyak tumbuh di tanah Arab yang mencerminkan pakaian kaum sufi yang sederhana ${ }^{8}$.

Secara terminology, menurut Muhammad Amin Al-Kurdy tasawuf adalah suatu ilmu yang dengannya dapat diketahui hal-ihwal kebaikan dan keburukan jiwa, cara membersihkannya dari sifat-sifat yang buruk dan mengisinya dengan sifat-sifat yang terpuji, cara melakukan suluk, melangkah menuju keridhaan Allah dan meninggalkan larangan-Nya menuju kepada perintah-Nya ${ }^{9}$. Tasawuf ialah usaha mengisi hati dengan hanya ingat kepada Allah yang merupakan landasan lahirnya ajaran al-hub atau cinta Illahi ${ }^{10}$. Tasawuf merupakan safa (kejernihan batin) dan musyahadah (persaksian

\footnotetext{
7 M. Sholihin dan Rosihon Anwar, Kamus Tasawuf (Bandung: Remaja Rosdakarya, 2002), hlm. 208-209.

${ }^{8}$ Rosihon Anwar, AkhlakTasawuf (Bandung: PustakaSetia, 2010), hlm. 143.

${ }^{9}$ Mustofa, AkhlakTasawuf ..., hlm. 203.

10 A.Rivay Siregar,Tasawuf dari Sufisme Klasik ke Neo-Sufisme (Jakarta: Raja Grafindo Persada, 1999), hlm. 34
}

langsung pada Tuhan). Kejernihan batin (safa al-qalb) merupakan sarana, sedang musyahadah merupakan derajat makrifatullah yang tertinggi ${ }^{11}$. Tasawuf adalah jalan untuk memasuki pintu Allah dengan mengikhlaskan ubudiyah/pengabdian hanya sematamata untuk Allah yang tiada sekutu bagi$\mathrm{Nya}^{12}$. Tasawuf ialah sebuah tuntunan yang dapat menyampaikan manusia kepada makrifatullah, dengan tariqah yang sebaik-baiknya dan akhlak yang seindah-indahnya ${ }^{13}$. Tasawuf disebut ilmu isyarah, karena kesaksian hati (musyahadah) dan pengungkapan rahasia (mukasyafah) ${ }^{14}$.

Dengan demikian, dapat dimaknai bahwa tasawuf adalah norma atau aturan agar orang berakhlak mulia, memerangi nafsu syahwat, membersihkan dan mempertinggi rohani dalam rangka mendekatkan diri kepada Allah dan mencari ridha-Nya. Tasawuf adalah jalan yang mesti ditempuh siapa saja yang ingin mencari keselamatan hidup di dunia dan akhirat, baik orang-

\footnotetext{
${ }^{11}$ Ibn Taimiyah, Pemberontakan Tasawuf, (Surabaya: JP. Book, 2007), hlm. 229.

12 Abdul Halim Mahmud, Hal Ihwal Tasawuf, (Terjemah Al-Munqidz min al-

Dhalal/Penyelamat dari Kesesatan, T.Tp: Daru al-Ilhya', tth), hlm. 13.

13 Abu Bakar Aceh, Pengantar Sejarah Sufi dan Tasawuf, (Semarang: Ramadhani, 1984), hlm. 36.

14 Abdu Al-Tawwab Abdul Hadi, Lambanglambang Sufi dalam Al-Qur'an, (Bandung: Pustaka, 1995), hlm. 2.
} 
orang yang hidup masa lalu, kini maupun yang akan datang. Tapi yang menjadi persoalan adalah bagaimana mengamalkan tasawuf tersebut, terutama pada zaman modern sekarang yang banyak memiliki tantangan dan tuntutan sesuai dengan kebutuhan zaman?

\section{Ciri, Tujuan dan Faedah Tasawuf}

$$
\text { Sebelum sampai pada }
$$

bagaimana mengamalkan tasawuf, terlebih dahulu harus dipahami mengenai ciri umum tasawuf, sehingga tidak menjadikan kesalahan dalam memahami apa dan bagaimana ajaran tasawuf itu. Berikut ini adalah ciri-ciri umum tasawuf yang sebenarnya dalam Islam:

a. Memiliki nilai-nilai moral. Artinya bahwa dalam bertasawuf harus ada peningkatan moralitas, maksudnya siapapun yang menekuni tasawuf berefek pada Akhlaqul Karimah ${ }^{15}$;

15 Akhlaq adalah ilmu yang berisi pembahasan dalam upaya mengenal tingkah laku manusia, kemudian memberikan nilai atau hukum kepada perbuatan tersebut, yaitu baik atau buruk. Lihat: Abudin Nata, Akhlak,..., hlm. 8. Akhlak adalah tabiat atau sifat seseorang, keadaan jiwa yang telah terlatih, sehingga dalam jiwa tersebut benar-benar telah melekat sifat sifat yang melahirkan perbuatan-perbuatan dengan mudah dan spontan tanpa dipikirkan dan dianganangan lagi. Ahmad Mustofa, Akhlak Tasawuf (Bandung: Pustaka Setia, 2014), hlm. 15. Dengan demikian, akhlaq karimah adalah perbuatan yang dilakukan atas kehendak dan kemauan sebenarnya, mendarah-daging dan b. Pemenuhan fana ${ }^{16}$ dalam realitas mutlak. Maksudnya orang yang bertasawuf bisa menfana'kan/ menghilangkan sifat-sifat buruk dalam dirinya dan tertanam sifat-sifat keilahian sehingga terwujud sikap insan dalam kehidupan;

c. Pengetahuan intuitif langsung ${ }^{17}$. Ketika orang bertasawuf telah mampu mengendalikan nafsu yang jelek menuju nafsu yang diridhai Allah

telah dilakukan secara kontinyu atau terusmenerus sehingga mentradisi dalam kehidupan seseorang. Perbuatan itu adalah perbuatan yang mulia. Abudin Nata, Akhlak, ..., hlm. 10.

${ }^{16}$ Fana' dalam tasawuf diartikan sebagai keadaan moral yang luhur. Hilangnya semua keinginan hawa nafsu seseorang, tidak ada pamrih dari segala perbuatannya, sehingga ia kehilangan segala perasaannya dan dapat membedakan segala sesuatu secara sadar, dan hilangnya segala kepentingan ketika melakukan sesuatu. Hilangnya sifat-sifat tercela dan tetap terpeliharanya sifat-sifat terpuji. Fana' terbagi menjadi tiga derajat, yaitu: (1) Transpormasi moral jiwa melalui pelenyapan hawa nafsu; (2) Abstraksi mental dari semua objek persepsi, pikiran, tindakan dan perasaan melalui konsentrasi pada pemikiran akan Tuhan, khususnya sifat-sifat-Nya; dan, (3) Berhentinya semua pemikiran sadar kecuali kesadaran itu sendiri (fana' al-Fana'). M. Solihin dan Rosihon Anwar, Kamus Tasawuf (Bandung: Pustaka Rosda Karya, 2002), hlm. 46-47.

${ }^{17}$ Menurut Ibnu Arabi, pengetahuan intuitif atau pengetahun esoteric adalah jenis pengetahuan yang paling penting, sekaligus merupakan inti filsafat mistis. Lihat: Elmansyah Al-Haramain, Paradigma Peradaban Tasawuf: Sebuah Pemaparan Awal (Pontianak: STAIN Pontianak Press, 2014), hlm. 145. Pengetahuan ini sering disebut sebagai pengetahuan Ladunni, atau pengetahuan yang dipancarkan langsung oleh Tuhan ke lubuk hati manusia tanpa melalui belajar atau argumentasi-argumentasi ilmiah. M. Solihin dan Rosihon Anwar, Kamus, ..., hlm. 91. 
maka hidupnya akan mendapatkan bimbingan dari Allah.

Berdasarkan ciri umum tasawuf

d. Timbulnya rasa kebahagiaan sebagai karunia Allah SWT. Sebagai akibat orang yang hidupnya bertasawuf akan selalu dalam bimbingan Allah sehingga terjauh dari dosa dan kesalahan maka hidup dalam kebahagiaan $^{18}$.

e. Penggunaan simbol-simbol pengungkapan yang biasa mengandung pengertian harfiah dan tersirat. Tidak menutup kemungkinan ketika seseorang betul-betul melakukan tasawuf dan diperoleh rasa kedekatan dengan Allah akan muncul rasa penyatuan dengan sang Khalik. Sehingga pengalaman spiritualnya jika diungkapkan dengan bahasa lisan atau tulisan muncul simbol-simbol pengungkapan. Maka berhati-hatilah dalam membahasakan dan memahaminya ${ }^{19}$.

18 Kebahagiaan merupakan tujuan kehidupan manusia. Menurut Ibnu Miskawaih, kebaikan adalah tujuan antara, sedangkan kebahagiaan adalah tujuan akhir. Kebaikan pada hakikatnya ada yang mulia, ada yang terpuji dan ada yang bermanfaat. Kebaikan yang dapat mengangkat martabat (kemuliaan) adalah hikmah (kebijaksanaan), kebaikan yang terpuji adalah aktifitas yang baik dan terpuji, dan kebaikan yang bermanfaat adalah sesuatu yang menjadi sarana, bukan hakikatnya, yaitu kaya, pangkat, dan sebagainya. M. Amin Syukur, Study Akhlak (Semarang: Lembaga Bimbingan dan Konsultasi Tasawuf/Lembkota, 2010), hlm. 4546.

19 Persoalan inilah yang sering muncul di kalangan sufi, sehingga ia harus mengalami

di atas, dapat dipahami bahwa tasawuf itu jelas tidak bertentangan dengan ajaran Islam, jauh dari kesesatan, apalagi menghambat modernitas yang sedang berkembang. Tasawuf merupakan sisi esoterik dalam Islam yang mengajarkan cara untuk mendekatkan diri kepada Allah SWT, dengan memperbaiki akhlak, menjauhi sifat-sifat buruk, mengendalikan nafsu, dan mencari ridho Allah SWT.

Cara-cara tersebut diajarkan sedemikian rupa dalam tasawuf agar seseorang yang berjalan di dalamnya dapat meraih tujuan utamanya. Tujuan utama tasawuf dapat diuraikan sebagai berikut: a) Menyelamatkan diri dari akidah syirik dan bathil; b) Melepaskan diri (takhalli) dari penyakit- penyakit hati. Pertama, penyakit hati yang tidak dirasakan oleh pemiliknya secara langsung yaitu penyakit kebodohan, syubhat dan keraguan. Ini adalah penyakit yang paling berbahaya. Kedua, penyakit hati yang secara langsung dapat dirasakan seperti rasa cemas,

nasip yang tragis. Misalnya, Suhrawardi AlMaqtul harus meregang nyawa di tiang gantungan akibat desakan para fuqoha. Amroeni Drajat, Kritik Falsafah Peripatetik (Yogyakarta: LKiS, 2005), hlm. 37. Hamzah Fansuri, AlHallaj, Al-Jili, bahkan di Indonesia terdengar kabar Syeikh Siti Jenar. Semuanya harus harus dihukum karena ungkapan-ungkapan mereka yang cenderung syatahiyat. 
gelisah, sedih dan amarah. Penyakit penyakit seperti itu kadang kala dapat disembuhkan dengan obat - obatan alamiah $^{20}$; c) Menghiasi diri (tahalli) dengan akhlak Islami; d) Menggapai derajat insan dalam ibadah (tajalli); e) Menstabilkan akidah shuhbah ilahiyah (persahabatan ketuhanan); dan, f) Menggapai kekuatan iman yang dulu pernah dimiliki sahabat Nabi SAW, menjalankan ilmu-ilmu syariat dan meniupkan ruh kehidupan yang Islami.

Ketika seseorang benar-benar mempelajari, memahami dan mengamalkan tasawuf, maka akan diperoleh faedah yang luar biasa dalam dirinya. Adapun faedah-faedahnya antara lain: 1) Membersihkan hati dalam berhubungan dengan Tuhan; 2) Membersihkan diri dari pengaruh materi; 3) Menerangi jiwa dari kegelapan; 4) Memperteguh dan menyuburkan keyakinan beragama; dan, 5) Mempertinggi akhlak.

\section{Inti Ajaran Tasawuf}

Inti ajaran tasawuf terletak pada dua istilah penting dalam terminologi tasawuf, yaitu: Maqamat dan Ahwal. Maqamat adalah jama' dari maqam, yang berarti tempat orang berdiri atau

\footnotetext{
${ }^{20}$ Hamka, Tasawuf Perkembangan dan Permukniaannya (Jakarta: Pustaka Panjimas, 1984), hlm. 112.
}

pangkal yang mulia. Menurut Abudin Nata, maqamat adalah jalan panjang yang harus ditempuh oleh seorang sufi untuk meraih posisi sedekat-dekatnya dengan Allah SWT ${ }^{21}$. Maqam adalah beragam mu'amalat (interaksi) dan mujahadah (perjuangan batin) yang dilakukan oleh seorang hamba di sepanjang waktunya. Jika seorang sufi menjalankan salah satu dari maqam itu, maka itulah maqamnya, sehingga ia berpindah ke maqam yang lebih tinggi ${ }^{22}$. Setiap ulama sufi berbeda dalam urutan maqam yang ditetapkannya, misalnya Muhammad al-Kalabadzi, maqamat diurutkan sebagai berikut: Taubat, Taqwa, Tawakkal, Ridha, Mahabbah dan Makrifah. Sedangkan Abu Nasr Saraj alThusi, menyebutkan maqamat sebagai: Taubat, Wara', Zuhud, Faqir, Sabar, Tawakal dan Ridha. Lain lagi dengan alImam Al-Ghazali, ia mengurutkan maqamat sebagai: Taubat, Sabar, Faqir, Zuhud, Tawakal, Makrifat dan Ridha ${ }^{23}$.

Terlepas dari urutan mana yang paling benar atau sering digunakan oleh para sufi, yang terpenting adalah bahwa maqamat merupakan inti ajaran tasawuf. Praktik riyadhah berupa maqamat inilah

\footnotetext{
${ }^{21}$ Abudin Nata, Akhlak Tasawuf (Jakarta: PT Raja Grafindo Persada, 2000), hlm. 193.

${ }^{22}$ Abdul Fatah, Tasawuf: Antara Al-Ghazali dan Ibnu Taimiyah (Jakarta: Khalifah, 2005), hlm. 108.

${ }^{23}$ Nasruddin, Historisitas dan Normatifitas Tasawuf (Jakarta: Aksi Media, 2008), hlm. 6364.
} 
yang menjadi ciri khas para sufi yang sedang menjalani kehidupan tasawuf. Melalui praktik ini pula, para sufi akan memperoleh ahwal (suatu keadaan sebagai pemberian Tuhan), sebagai bagian dari tanda kedekatan diri dengan Tuhan-nya. Belumlah dianggap sufi seseorang, ketika ia belum menjalani maqamat dan memperoleh ahwal.

\section{Sebab-sebab Anti Tasawuf}

Ada banyak sebab orang salah paham terhadap tasawuf, sehingga memunculkan pemahaman negatif dan anti terhadap sufisme. Menurut M. Amin Syukur, pandangan negatif terhadap tasawuf disebabkan oleh adanya pemahaman ulama klasik, bahwa yang namanya tasawuf adalah mengisolasikan diri dari keramaian dunia, termasuk di dalamnya masalah harta, pangkat atau jabatan. Pemahaman ini didorong oleh faktor pemahaman sepihak terhadap nash yang cenderung mendeskreditkan dunia. Selain itu, situasi dan kondisi pada saat munculnya gerakan tasawuf - sekitar abad II-III Hijriyah - menuntut para ulama klasik menarik diri dari keramaian dunia ${ }^{24}$.

\footnotetext{
${ }^{24}$ M. Amin Syukur, Menggugat Tasawuf: Sufisme dan Tanggung Jawab Sosial Abad 21 (Yogyakarta: Pustaka Pelajar, 2012), hlm. v.
}

Jika ditilik dari sejarah, maka tidak dapat dipungkiri bahwa pada awal munculnya gerakan tasawuf, para ulama memang mencoba menarik diri dari halhal duniawi: politik, ekonomi, bahkan sosial dan budaya, akibat situasi dan kondisi yang sangat tidak memungkinkan. Oleh karena itu, kehidupan para ulama sufi pada umumnya dalam kesederhanaan, banyak menghabiskan waktu untuk beribadah, dan terlihat selalu asyik dengan zikirnya yang panjang, seolah tanpa peduli dengan sekitar ${ }^{25}$.

Barangkali karena persoalan kenyataan sejarah itulah, yang membuat masyarakat awam menjadi berfikiran negatif terhadap tasawuf, karena yang dilihat hanya permukaannya saja. Jika digabungkan dengan pandanganpandangan modern terhadap tasawuf, maka dapat disimpulkan bahwa

\footnotetext{
${ }^{25}$ Gerakan tasawuf (baca: Zuhud) muncul pada masa Islam dalam kondisi yang sangat memprihatinkan di masa kekhalifahan Bani Umayyah (Yazid: 61-64 H atau 680-683 M), di mana Yazid dikenal sebagai khalifah yang tidak mempedulikan ajaran-ajaran agama, jauh dari teladan Rasulullah SAW. Karenanya, para ulama mengambil jalan protes dengan cara menyerukan masyarakat untuk hidup zuhud, sederhana, saleh, dan tidak tenggelam dalam buaian hawa nafsu. Salah satunya adalah Abu Dzar al-Ghifari. Sebelumnya, sudah ada gerakan yang sama yang dilakukan oleh kelompok Tawwabin, dipimpin oleh Mukhtar bin Ubaid al-Tsaqafi (terbunuh tahun $68 \mathrm{H}$ ). Tim Penyusun, Ensiklopedi Islam Jilid V (Jakarta: PT Ichtiar Baru - Van Hoeve, 2003), hlm. 81-82.
} 
pandangan negatif anti tasawuf disebabkan oleh beberapa faktor, yaitu:

a. Adanya Penggunaan Istilah-istilah Tasawuf Tidak pada Tempatnya.

Tasawuf memiliki khazanah terminologi yang kaya, dalam dan penuh makna. Beberapa terminologi tasawuf yang acap menjadi polemik antara hulul, wahdat al-wujud, nur muhammadi, mukasyafah, dan lain sebagainya. Istilah ini memiliki pengertian filsafati yang sangat mendalam, tidak bisa hanya dipahami sekilas, misalnya istilah hulul: lalu dipahami bahwa Allah merasuki tubuh-tubuh manusia tertentu, kemudian bersemayam di dalamnya. Itu artinya menyamakan Tuhan sebagai makhluk, sehingga wajar dianggap sesat.

Doktrin hulul memang muncul dari pemahaman Abu Mansyur alHallaj, sebagaimana Nur Muhammadi dan Wahdat al-Adyan. Hulul berarti mengisi/menempati, di sini Allah SWT mengisi/menempati tubuh manusia yang telah hilang sifat kemanusiaannya melalui proses fana'. Jadi, ketika manusia telah mampu menghilangkan sifat kemanusiaannya, sebagaimana manusia terdiri dari 2 unsur (jasmani dan ruhani), jasmani bersifat bendawi, ruhani bersifat ilahi, maka tubuh yang bendawi itu dimasuki oleh Allah SWT ketika hilang sifat kebendaannya. Doktrin ini sangat dalam, tidak mudah mengungkapkannya dengan katakata, kecuali sesorang itu mengalaminya sendiri. Demikian juga dengan pemahaman atas Nur Muhammadi dan Wahdat al-Adyan. Selain itu, istilah-istilah dalam tasawuf kelihatan mudah diucapkan, akan tetapi sulit untuk dilakukan. Karenanya, penggunaan istilah-istilah tasawuf yang tidak pada tempatnya, akan melahirkan ekses negatif terhadap tasawuf itu sendiri.

b. Adanya Oknum yang mengafiliasikan diri pada tasawuf padahal bukan.

Saat ini banyak orang yang nampaknya terafiliasi ke dalam ajaran tasawuf tertentu, akan tetapi mereka tidak menjalani kehidupan tasawuf secara baik dan benar. Kasus-kasus penyimpangan ajaran tasawuf, terutama dalam aliran-aliran tarekat tertentu yang mengaku memiliki garis kesufian yang jelas, akan tetapi sesungguhnya tidak lebih dari sekedar ilmu kebatinan yang cenderung menyesatkan. Oknum seperti ini, biasanya memang pernah berafiliasi ke aliran tarekat tertentu, namun keluar dari aliran tersebut dan membentuk aliran tersendiri. 
Umumnya karena motif ekonomi dan nafsu duniawi yang dengan banyaknya pengikut, berharap memperoleh keuntungan finansial. Terkadang ajarannya aneh dan sangat jauh dari tasawuf.

$$
\text { Karena ajarannya }
$$

menyimpang dan diketahui oleh khalayak, maka nama tasawuf menjadi tercemar. Itulah sebabnya mengapa kemudian muncul lembagalembaga yang mengurusi masalah tarekat, misalnya: JATMAN (Jama'ah Ahli Thariqah Mu'tabarah AlNahdliyah) dan JATMI (Jama'ah Ahli Thariqah Mu'tabarah Indonesia). Lembaga ini berusaha menjamin keabsahan tarekat yang berkembang, baik di kalangan Nahdlatul Ulama (NU), maupun di Indonesia pada umumnya.

c. Hanya Melihat Ungkapan-ungkapan Syathahat Para Sufi.

Ungkapan-ungkapan syatahat adalah ungkapan meracau yang kadang keluar dari seorang sufi yang sedang "dimabuk" cinta kepada Tuhannya. Umumnya orang yang sedang jatuh cinta, maka ungkapan yang keluar dari bibirnya ataupun tulisannya akan terlihat aneh bagi orang lain. Seperti kasus Al-Jilli yang ditanya tentang dirinya, malah menjawab dirinya adalah Tuhan.

Mirip seperti seorang pemuda yang tengah jatuh cinta, ketika ditanya tentang kekasinnya, ia menjawab bahwa dirinya dan kekasihnya adalah satu, "Dia adalah Aku dan Aku adalah Dia". Jika melihat tasawuf dari sudut pandang syatahiyat semacam ini, tentu akan melahirkan pandangan-pandangan yang berbeda, aneh, di luar akal sehat dan menyesatkan. Itulah sebabnya, jika hanya melihat tasawuf dari ungkapan syatahat, maka akan terlihat bahwa tasawuf itu berlebihan dan tanpa dasar.

d. Hanya Melihat Praktek-praktek dari Doktrin Sufisme yang Disalahgunakan

Ada beberapa kekhasan dalam ajaran tasawuf, khususnya tarekat. Praktek-praktek tarekat sangat mungkin disalah-gunakan, misalnya: Doktrin Tawajjuh (Membayangkan wajah sang guru ketika hendak beribadah); Bai'at (mengambil sumpah untuk taat pada guru); dan lain sebagainya. Jika tawajuh disalahgunakan dari ajaran utamanya yaitu upaya melatih konsentrasi menjadi hal-hal lain, maka tasawuf akan tercemar dan dianggap mengada-ada tanpa dasar 
hukumnya. Atau doktrin bai'at disalahgunakan oleh Mursyid, maka anggapan miring terhadap ajaran tasawuf tidak bisa dielakkan.

Celakanya, banyak doktrindoktrin semacam ini disalahgunakan oleh oknum-oknum tertentu, sehingga menambah buram wajah tasawuf di masyarakat. Karenanya, jika masyarakat awam hanya melihat ajaran tasawuf yang telah disalahgunakan, maka barang pasti bahwa tasawuf akan menjadi sangat buruk dalam pandangan.

\section{Tantangan Modernitas}

Istilah modernitas diderivasikan dari istilah modern. Istilah modern pertama kali muncul pada abad ke-16 (sekitar tahun 1500-an di Eropa), berasal dari bahasa Latin 'moderna' yang artinya sekarang, baru, atau saat kini. Melalui istilah inilah kata modernitas itu muncul. Modernitas bukan hanya menunjuk pada suatu periode, melainkan juga suatu bentuk kesadaran yang terkait dengan kabaruan (Inggris: Newness), karena itu istilah perubahan, kemajuan, revolusi, pertumbuhan adalah istilah-istilah kunci kesadaran modern. Pemahaman tentang modernitas sebagai suatu bentuk kesadaran itu, lebih mendasar dari pada pemahaman-pemahaman yang bersifat sosiologis ataupun ekonomis. Dalam pemahaman-pemahaman terakhir ini, orang menunjuk pada tumbuhnya sains, teknik dan ekonomi kapitalistis sebagai ciri-ciri masyarakat modern ${ }^{26}$.

Modernitas hampir sama dengan istilah modernism, hanya saja modernism lebih dimaknai sebagai sesuatu yang berada pada tataran konseptual; ideologi, sedangkan modernitas lebih mengarah pada tataran praktis atau konkretisasi dari ideology modernism tersebut. Akan tetapi keduanya adalah sama, yaitu menyampaikan realitas kemodernan. Kata modern sebetulnya sangat menyingkap suatu kesadaran diri yang historis, dari orang tertentu atau zaman tertentu serta menandai adanya perbedaan antara kondisi masa sekarang dengan kondisi masa lalu. Oleh karena itu, istilah modernitas di sini dapat dimaknai sebagai wujud nyata dari realitas kemodernan yang terjadi saat ini di masyarakat ${ }^{27}$.

Modern adalah sikap dan cara berfikir dan bertindak sesuai dengan tuntutan zaman. Menurut Deliar Noer, sebagaimana dikutip oleh Abudin Nata,

\footnotetext{
${ }^{26}$ F. Budi Hardiman, Filsafat Modern Dari Machiavelli sampai Nietzsche: Suatu Pengantar dengan Teks dan Gambar (Jakarta: Gramedia Pustaka Utama, 2007), hlm. 19.

27 Emanuel Wora, Perenialisme: Kritik atas Modernisme dan Postmodernisme (Jakarta: Penerbit Kanisius, 2006), hlm. 37.
} 
ciri-ciri masyarakat modern adalah sebagai berikut ${ }^{28}$ :

1. Bersifat Rasional

Masyarakat modern lebih mengutamakan pendapat akal pikiran, dari pada pendapat emosi. Mereka mengedepan pendapat yang dapat diterima oleh akal. Logis dan empiris. Karenanya, mereka tidak percaya pada tahayul dan kegaiban-kegaiban yang di luar nalar, meskipun mereka juga sering menjumpainya sebagai pengalaman. Bersifat rasional berarti segala sesuatunya bersifat logis, sistematis dan kritis sebagai hasil dari berfikir rasional ${ }^{29}$;

2. Berfikir Futuristik

Masyarakat modern bersifat futuristik. Mereka berfikir untuk masa depan yang lebih baik, terprogram. Tidak hanya berfikir saat ini atau keperluan saat ini saja, melainkan mempersiapkan strategi untuk masa depan;

3. Menghargai Waktu

\footnotetext{
${ }^{28}$ Abudin Nata, Akhlak Tasawuf..., hlm. 279-280.

29 Berfikir Rasional merupakan salah satu ciri awal pemikiran filsafat. Berfikir rasional bermula dari berfikir kritis. Berfikir kritis berarti membakar kemauan untuk terus menerus mengevaluasi argument-argumen yang mengklaim diri benar. Seseorang yang berfikir kritis tidak akan mudah menggenggam sesuatu yang dianggap benar sebelum benar-benar dipersoalkan dan diuji hingga terbukti kebenarannya. Berfikir rasional harus dibarengi dengan berfikir logis, sistematis dan kritis sebagai ciri utamanya. Jan Hendrik Rapar, Pengantar Filsafat (Yogyakarta: Penerbit Kanisius, 1996), hlm. 23-24.
}

Masyarakat modern selalu berfikir bahwa waktu sangat berharga dan dimanfaatkan secara maksimal. Ada istilah 'waktu adalah uang', sehingga mereka tidak ingin menyia-nyiakan waktu untuk sesuatu yang belum jelas untung ruginya. Waktu yang ada dimanfaatkan sebaik mungkin, terprogram dan dilaksanakan sesuai schedule yang telah disusun sebelumnya.

4. Bersikap Terbuka

Masyarakat modern bersikap terbuka (open minded), artinya siap menerima masukan, saran, kritikan dan apapun bentuknya dari siapapun demi perbaikan hidup dan kehidupan; dan,

5. Berfikir Obyektif

Masyarakat modern melihat segala sesuatu dari sudut fungsi dan kegunaannya.

Sedangkan menurut Atho' Muzhar, masyarakat modern ditandai oleh lima hal: Pertama, berkembangnya Mass Culture. Kedua, tumbuhnya sikapsikap yang lebih mengakui kebebasan bertindak manusia menuju perubahan masa depan. Ketiga, tumbuhnya berfikir rasional. Keempat, tumbuhnya sikap hidup yang materialistik. Kelima, meningkatnya laju urbanisasi ${ }^{30}$.

30 M. Atha Muzhar, Guru Pendidikan Agama Islam dalam Perspektif Tantangan Hidup Bergama di Masa Depan (Jakarta: Balai Pustaka, 1993), hlm. 11-12. 
Melihat karakteristik masyarakat modern seperti di atas, tentu saja akan melahirkan berbagai problem kehidupan, sekaligus tantangan bagi tasawuf dan keagamaan. Problematika masyarakat modern, menurut Abuddin Nata disebutkan bahwa sebab kehadiran ilmu pengetahuan dan tehnologi telah menghadirkan sejumlah problematika masyarakat modern antara lain ${ }^{31}$ : a) Disintegrasi IImu Pengetahuan; b) Kepribadian yang terpecah; c) Penyalahgunaan Iptek; d) Pendangkalan iman; e) Pola hubungan matrialistik; f) Menghalalkan segala cara; dan, g) Stres dan frustasi.

Masyarakat modern adalah masyarakat yang cenderung menjadi sekuler. Hubungan antara anggota masyarakat tidak lagi atas dasar atau prinsip tradisi atau persaudaraan, tetapi pada prinsip-prinsip fungsional pragmatis. Masyarakatnya merasa bebas dan lepas dari kontrol agama dan pandangan dunia metafisis. Ciri-cirinya yang lain adalah penghilangan nilai-nilai sakral terhadap dunia, meletakkan hidup manusia dalam konteks sejarah dan penisbian nilai-nilai. Masyarakat modern menyimpan problem hidup yang sulit di pecahkan. Rasionalisme, sekularisme, materialisme dan lain sebagainya ternyata tidak menambah kebahagiaan dan ketentraman hidupnya, melainkan sebaliknya yaitu menimbulkan kegelisahan hidupnya karena mengalami krisis spiritual. Untuk mengatasi hal tersebut tidak ada jalan lain menurut Hossein Nasr harus kembali kepada agama melalui tasawuf.

Mengutip pendapat Komarudin Hidayat mengapa sufisme perlu dikembangkan/ dimasyarakatkan:

Pertama, turut serta terlibat dalam berbagai peran dalam menyelamatkan kemanusiaan dari kondisi kebingungan akibat hilangnya nilai-nilai spiritual. Kedua, memperkenalkan literatur atau pemahaman tentang aspek esoteris (kebatinan) Islam. Ketiga, untuk memberikan penegasan kembali bahwa sesungguhnya aspek esoteris Islam, yakni sufisme, adalah jantung ajaran Islam, sehingga jika wilayah ini kering dan tidak berdenyut, maka keringlah aspek-aspek lain ajaran Islam. Nilai-nilai Spiritual yang harus dicapai dalam menghadapi abad modern ini adalah hidup yang bersungguh-sungguh, bersyukur, bisa menghargai waktu, berfikir positif, silaturrahmi, berjiwa besar, belajar dan mengajar, bertobat jika telah melakukan dosa dan kesalahan dan jangan lupa berdoa kepada Allah SWT.

${ }^{31}$ Abudin Nata, Akhlak Tasawuf..., hlm. 289-293. 
Untuk menyelesaikan persoalan tersebut tasawuf punya metode yaitu dengan jalan menempuh Maqamat dan ahwal. Maqomat adalah jama' dari maqom yang mengandung arti kedudukan, yakni kedudukan hamba dalam pandangan Allah, menurut apa yang diusahakan menurut Ibadah, perjuangan, latihan dan perjalanan menuju Allah SWT. sedangkan ahwal adalah jama dari hal yang berarti sifat atau keadaan sesuatu yakni keadaan atau kondisi psikologis yang dirasakan ketika seseorang mencapai maqam tertentu.

Maqam-maqam yang harus di jalani yaitu: Tobat, Zuhud, Faqir, Sabar, Syukur, Ridha, dan Tawakkal. Jika maqamat telah dilakukan dengan sungguh, benar dan istiqamah maka ahwal yang akan diperoleh di antaranya: Muhasabah dan muraqabah (Waspada \& mawas diri), Hubb (cinta), Khauf dan Raja' (takut \& berharap), Syauq (rindu), Uns (intim), Thuma'ninah (tentram), Musyahadah (penyaksian), dan Yaqin (percaya). Selain melalui tahapantahapan maqamat dan ahwal tersebut untuk memperoleh ketinggian spiritual dan ma'rifat maka seseorang harus melakukan upaya-upaya tertentu, yaitu: Riyadhah dan mujahadah; Tafakur; Tadzkiyatun nafs; dan, Dzikrullah. Jika totalitas jiwa dan hatinya telah suci dan dipenuhi dzikrullah, tidak mustahil bila hidupnya dipenuhi kearifan dan dalam bimbingan Allah, maka hidupnya selamat dan bahagia dunia dan akherat.

\section{Kesimpulan}

Berdasarkan uraian di atas, dapat disimpulkan beberapa hal berikut:

1. Tasawuf adalah salah satu dimensi ke-Islam-an yang dibangun dari pilar Ihsan untuk menguatkan Iman dan Islam. Tasawuf bergerak dari sisi esoterik, terfokus pada dimensi ruhaniah. Tasawuf memberikan makna atas hakikat keimanan seseorang yang dilakukan dengan tetap menjunjung tinggi syari'at. Orang yang menjalankan syari'at dengan tanpa diiringi dengan hakikat (tasawuf), maka ibadahnya akan menjadi formalitas belaka, tanpa esensi yang dapat dirasakan, baik bagi diri sendiri maupun bagi sekitar. la akan terjebak pada formalisme yang kaku tanpa makna. Namun di sisi lain, jika hanya tasawuf (hakikat) tanpa syari'at, ibadah seseorang akan tersesat pada jalan yang salah yang tidak diridhai oleh Allah SWT.

2. Modernitas adalah kesadaran akan perubahan yang senantiasa terjadi di masyarakat modern. Modernitas berarti penerapan atas ideologi modern. Modernitas, bukan berarti 
tanpa masalah. Modernitas membawa persoalan-persoalan kehidupan yang pelik, akibat adanya perubahanperubahan yang terjadi di masyarakat: a) Terjadinya pemisahan atas ilmu pengetahuan (Umum dan Agama; Sains dan Sosial; dan lain sebagainya); b) Pecahnya kepribadian masyarakat akibat benturan kepentingan (untung-rugi, pragmatism, hedonisme berlebihan, dan lain sebagainya); c) Maraknya Penyalahgunaan Iptek (cyber crime, prostitusi, narkoba dan lain-lain; d) Banyaknya kasus pendangkalan iman (akibat teknologi informasi yang banyak berisi informasi hoax); e) Pola hubungan matrialistik (berasaskan kapitalisme); f) Menghalalkan segala cara (yang penting berhasil); dan, g) Stres dan frustasi.

3. Kesalahpahaman atas tasawuf Banyak faktor yang menyebabkan kesalahpahaman terhadap tasawuf, antara lain: a) Karena hanya melihat tasawuf dari sisi tarekat yang menyimpang; b) Karena hanya melihat tasawuf dari oknum yang menyimpang; dan, c) Karena hanya melihat tasawuf dari sisi pendapat ulama atau orang atau kelompok yang menentang.

4. Tasawuf di era modern.
Kemajuan dan kemakmuran masyarakat dunia telah tercukupi di era modern, dari hasil penemuanpenemuan yang terus berkembang. Sementara itu tasawuf merupakan sarana pemenuhan atas kebutuhan manusia dari sisi ruhaniah. Persoalan-persoalan masyarakat modern, seperti pecahnya kepribadian, penyalahgunaan iptek, pendangkalan iman, materialistis, dan frustasi, dapat diselesaikan dengan tasawuf. Tasawuf dengan tarekat (metode)-nya, selama ini terbukti mampu menyelesaikan persoalanpersoalan masyarakat modern.

\section{E. Daftar Pustaka}

Aceh, Abu Bakar. Pengantar Sejarah Sufi dan Tasawuf, (Semarang: Ramadhani, 1984).

Al-Haramain, Elmansyah. Paradigma Peradaban Tasawuf: Sebuah Pemaparan Awal (Pontianak: STAIN Pontianak Press, 2014).

Anwar, Rosihon. AkhlakTasawuf (Bandung: PustakaSetia, 2010).

Corbin, Henry. Imajinasi Kreatif Sufisme Ibn Arabi (Yogyakarta: LKiS, 2002).

Drajat, Amroeni. Kritik Falsafah Peripatetik (Yogyakarta: LKiS, 2005).

Fatah, Abdul. Tasawuf: Antara AlGhazali dan Ibnu Taimiyah (Jakarta: Khalifah, 2005).

Hadi, Abdu Al-Tawwab Abdul. Lambanglambang Sufi dalam Al-Qur'an, (Bandung: Pustaka, 1995). 
Hamka, Tasauf Modern (Jakarta:Pustaka Panjimas, 1990).

Hamka, Tasawuf Perkembangan dan Permukniaannya (Jakarta: Pustaka Panjimas, 1984).

Hardiman, F. Budi. Filsafat Modern Dari Machiavelli sampai Nietzsche: Suatu Pengantar dengan Teks dan Gambar (Jakarta: Gramedia Pustaka Utama, 2007).

Kabbani, Syeikh Muhammad Hisyam. Ensiklopedia Akidah Ahlusunah: Tasawuf dan Ihsan, Antivirus Kebatilan dan Kezaliman (Jakarta: PT Serambi Semesta, 2007).

Mahmud, Abdul Halim. Hal Ihwal Tasawuf, (Terjemah Al-Munqidz min al-Dhalal/Penyelamat dari Kesesatan, T.Tp: Daru al-Ilhya', tth).

Mustofa, Ahmad. Akhlak Tasawuf (Bandung: Pustaka Setia, 2014).

Muzhar, M. Atho. Guru Pendidikan Agama Islam dalam Perspektif Tantangan Hidup Bergama di Masa Depan (Jakarta: Balai Pustaka, 1993).

Nasruddin, Historisitas dan Normatifitas Tasawuf (Jakarta: Aksi Media, 2008).

Nata, Abudin. Akhlak Tasawuf (Jakarta: PT Raja Grafindo Persada, 2000).
Penyusun, Tim. Ensiklopedi Islam Jilid V (Jakarta: PT Ichtiar Baru - Van Hoeve, 2003).

Rapar, Jan Hendrik. Pengantar Filsafat (Yogyakarta: Penerbit Kanisius, 1996).

Sholihin, M. dan Anwar, Rosihon. Kamus Tasawuf (Bandung: Remaja Rosdakarya, 2002).

Siregar, A.Rivay. Tasawuf dari Sufisme Klasik ke Neo-Sufisme (Jakarta: Raja Grafindo Persada, 1999).

Syukur, M. Amin. Menggugat Tasawuf: Sufisme dan Tanggung Jawab Sosial Abad 21 (Yogyakarta: Pustaka Pelajar, 2007).

Syukur, M. Amin. Menggugat Tasawuf: Sufisme dan Tanggung Jawab Sosial Abad 21 (Yogyakarta: Pustaka Pelajar, 2012).

Syukur, M. Amin. Study Akhlak (Semarang: Lembaga Bimbingan dan Konsultasi Tasawuf/Lembkota, 2010).

Syukur, M. Amin. Tasawuf Sosial (Yogyakarta: Pustaka Pelajar, 2004).

Taimiyah, Ibn. Pemberontakan Tasawuf, (Surabaya: JP. Book, 2007).

Wora, Emanuel. Perenialisme: Kritik atas Modernisme dan Postmodernisme (Jakarta: Penerbit Kanisius, 2006). 